\title{
The effect of product diversity and service quality on loyalty with customer satisfaction as an intervening variable (Study of Toko Pertanian Subur, Pace Nganjuk District)
}

\author{
Fani Firmansyah \\ Faculty of Economics, UIN Mulana Malik Ibrahim, Malang \\ Firmansyahfani@yahoo.co.id \\ Ni'amin Nurin Nasikha \\ Faculty of Economics, UIN Mulana Malik Ibrahim, Malang \\ Niaminurinnasikha@gmail.com
}

\begin{abstract}
Customer orientation is one of the solutions to overcome competition between businesses in this era. As many similar businesses have emerged, generating customer loyalty is one of the company's strategies to compete and increase the sales of products. The objective of this study is to determine the effect of product diversity and quality of service on loyalty in terms of customer satisfaction. The quantitative approach is chosen in this study to obtain the expected results, while the path analysis test and the classical assumption test are used as the analysis model. The data source referred to in this study is the result of a questionnaire in the form of respondents' responses. The population in this study were all customers of the "Toko Pertanian Subur". A total of 98 respondents were taken as the sample which was determined by purposive sampling technique. After conducting the research, it is found that product diversity and service quality had a positive effect directly on customer loyalty with a significance level of less than alpha (0.050). The product diversity variable also does not have a mediating effect on loyalty when viewed from customer satisfaction. In addition, there is no mediating effect between service quality variables on loyalty in terms of customer satisfaction.
\end{abstract}

Keywords: Product Diversity, Service Quality, Customer Satisfaction and Customer Quality

\begin{abstract}
Abstrak
Orientasi pada pelanggan menjadi salah satu solusi mengatasi persaingan antar bisnis di era ini. Seiring banyaknya bisnis sejenis yang muncul, membangkitkan loyalitas pelanggan menjadi salah satu strategi perusahaan untuk mampu bersaing dan meningkatkan penjualan. Penelitian ini bertujuan untuk mengetahui pengaruh keanekaragaman produk dan kualitas pelayanan
\end{abstract}


terhadap loyalitas ditinjau dari kepuasan pelanggan. Pendekatan kuantitatif dipilih dalam penelitian ini untuk mendapatkan hasil yang diinginkan, sedangkan model analisis yang digunakan adalah uji analisis jalur dan uji asumsi klasik. Sumber data yang dimaksud dalam penelitian ini adalah hasil angket berupa tanggapan responden. Populasi dalam penelitian ini adalah seluruh pelanggan Toko Pertanian Subur. Sebanyak 98 responden diambil sebagai sampel yang ditentukan dengan teknik purposive sampling. Setelah dilakukan penelitian, peneliti menemukan bahwa keanekaragaman produk dan kualitas pelayanan secara langsung berpengaruh positif terhadap loyalitas pelanggan dengan tingkat signifikansi kurang dari alpha (0.050). Variabel keanekaragaman produk juga tidak memiliki efek mediasi terhadap loyalitas saat ditinjau dari kepuasan pelanggan. Selain itu, tidak ditemukan pengaruh mediasi antara variabel kualitas layanan terhadap loyalitas ditinjau dari kepuasan pelanggan.

Kata Kunci: Keanekaragaman Produk, Kulitas Pelayanan, Kepuasan Pelanggan, dan Loyalitas Pelanggan

\section{INTRODUCTION}

Retailers are often seen as businesses that only sell products. However, retail also provides many services, such as delivery services to homes or other services that can provide added value to goods and services that will be consumed by end customers (Utami, 2010). In the process of determining consumer purchasing decisions, they will go through 5 stages, namely problem recognition, information search, evaluation of alternatives, purchase decisions, and post-purchase behavior (Kotler, 2009). Postpurchase behavior is the final result where in this stage could be seen whether the consumer is satisfied or not after making a purchase. So that, we know the customer is an important factor in a retail business. At every store/ retail that is visited by consumers, they will surely have hopes of fulfilling their satisfaction. One of them is the fulfillment of everything that customers need. As well as customer expectations for services provided by the store/ retail to them.

Convinced and loyal customers are an opportunity to obtain new customers. Managing existing customers is viewed generally more profitable than customer turnover because attracting new customers will consume cost five times higher than the cost of maintaining the existing customer (Kotler et al, 2006). Constructing customer loyalty can be one of companies' strategies to increase sales. Currently, establishing loyalty that is influenced by customer satisfaction is a company goal. As the level of existing loyalty to consumers can provide clues to increase the profits in the long term. 
The variety of products provided by the store is an important factor in retail business competition. This is due to the diversity products offered by retailers such as the type of product, brand, size, quality and availability that makes it easy for customers to pick and purchase these products based on their needs. Consumers will give a good impression to a store, if the store can provide the goods needed and desired by consumers. Apart from product diversity, service quality also effects the purchasing decisions. Good service quality will provide comfort and satisfaction to customers when making purchases.

Toko Pertanian Subur is one of the retail businesses that provides various types of agricultural production facilities such as agricultural tools, pesticides, plant vitamins, corn seeds, rice - vegetables, and fertilizers. In forming customer loyalty and customer satisfaction, Toko Pertanian Subur has provided a variety of products and good quality service to customers in the hope that customers want to make repeat purchases, thus the store can compete and increase the number of sales. However, in this case Toko Pertanian Subur experienced fluctuations from sales from 2015 - 2018, this can be seen from the following data:

Table 1. Toko Pertanian Subur Sales 2015 - 2018

\begin{tabular}{|c|c|}
\hline Year & Number of Sales \\
\hline 2015 & Rp. 5.948.374.000 \\
\hline 2016 & Rp. 3.639.439.000 \\
\hline 2017 & Rp. 4.223.530.000 \\
\hline 2018 & Rp. 4.483.297.000 \\
\hline
\end{tabular}

In line with the description on the background of the problem above, the researchers are interested in examining and carrying out a research with the title "The Impact of Product Diversity and Service Quality on Loyalty with Customer Satisfaction as an Intervening Variable (Study of Subur Agricultural Stores, Pace Nganjuk District)".

1. Product Diversity

According to Kotler \& Keller (Tjiptono \& Chandra, 2012), a product is defined as anything that can be offered to meet the needs and desires of consumers. Based on Simammora (2004) the definition of product diversity is a group (diversity) of product and elements offered by certain sellers to buyers. Product completeness is the availability of all types of products offered to be owned, used or consumed by customers produced by a manufacturer (Kotler, 2002). Product diversity creates the availability of goods in very varied quantities and types, giving many choices in the consumer 
shopping process. In the shopping process, consumers often make decisions in buying an item unplanned or not in accordance with the previous shopping list. So that, to provide a variety of products will have a positive impact on retailers/ businesses.

\section{Service Quality}

In accordance with Kotler (2002) the definition of service is any action or activity that can be suggested by one party to another, which is basically intangible and does not occur in any ownership. Stated by Tjiptono (2005), service quality is an effort to fulfill customer needs and desires, and the accuracy of their delivery to balance customer expectations. Service is the most important factor for consumers. The better the quality of service provided by a company, the better the customer satisfaction will be. Service quality is formed by the ability of the company to fulfill every expectation and desire of every customer need. The value created in customer satisfaction depends on how the company meets customer expectations.

\section{Customer Satisfaction}

Customer satisfaction is the feeling of pleasure or disappointment of customers that comes from a comparison between product performance and their expectations (Rivai, 2012). If the performance of the product is as expected, the customer will be satisfied and happy. Meanwhile, if the product performance is not in accordance with what the customer expects, the customer will not be satisfied. Basically, the notion of customer satisfaction covers the difference between expectations and performance or perceived results (Tjiptono, 1997).

4. Customer Loyalty

As stated by Tjiptono (2007), loyalty is a customer assurance to a store, brand or supplier which is based on a positive attitude that is reflected in the form of consistently repeated purchases. In the meantime, Lupiyoadi (2001) defines customer loyalty as a condition in which customers have a positive attitude towards an object, have a commitment to that object, and intend to continue their purchases in the future. Customer loyalty can also be defined as someone who buys, especially someone who buys an item continuously (Hasan, 2008). From some of the definitions above, it can be wrapped up that customer loyalty is the ability of customers to purchase goods continuously to satisfy their desire to have a product, thus creating a relationship between consumers and the company, product, or brand.

5. Review of Related Literature

Research by Hartono (2018) entitled "Analysis of Effect of Quality of Services Towards Loyalty Customers with Satisfaction Customers for variable 
Intervening in Toko Kalimas" retrieved result that quality of service effects the satisfaction of customers in the Toko Kalimas. Satisfaction of customers' influence on the loyalty of the customers in the Toko Kalimas. Quality of service impacts on the loyalty of the customers in the Toko Kalimas. Customer Satisfaction serves as a variable intervening between the quality of service to the loyalty of the customers in the store Kalimas .

Gunawan \& Sesilya (2016) did a research "The Effect of Service Quality Towards Loyalty Customers with Satisfaction Consumers as Variable Intervening in Toko Bintang Terang" found that there is the influence of the quality of service to the satisfaction of the consumer in the Toko Bintang Terang, Bangil. There is effect between the satisfaction of consumers against the loyalty of consumers in Toko Bintang Terang, Bangil. It proves that there is an influence between service quality on consumer loyalty at Toko Bintang Terang, Bangil. There is customer satisfaction who serves as a variable intervening between the quality of service to the loyalty of consumers Toko Bintang Terang, Bangil.

Hasanah et al., (2012) researched with the title of "The Effect of Diversity Menu, Price and Quality of Services Towards Loyalty Customers with satisfaction as Variable Intervening at Waroeng "SS" (Spesial Sambel) Surabaya. This research shows that there is a significant influence between menu diversity, prices, and service quality on customer satisfaction. There is significant effect between the diversity of the menu, prices, against the loyalty of customers. There is a significant but negative influence between service quality on customer loyalty. There is impact that significantly occurred between the satisfaction of customers to the loyalty of the customers. There is a significant influence between menu diversity, price and the quality of service on customer loyalty with satisfaction as an intervening variable.

\section{RESEARCH METHOD}

\section{Research Location}

The object of the research was carried out on customers who made purchases at Toko Pertanian Subur located in Jegles Area, Plosoharjo Village, Pace District, Nganjuk Regency. Toko Pertanian Subur is one of the lower-middle agricultural shops that provides various types of agricultural drugs and tools. The reason the researchers chose Toko Pertanian Subur as the object of study seen from the average of the loyalty level of customer Toko Pertanian Subur, since they tend to feel satisfied by the service that is given.

\section{Population and Sample}


The population were the customers of Toko Pertanian Subur using purposive sampling technique. Criteria in sampling technique is the customer who has been doing a purchase on Toko Pertanian Subur as much as three times or more.

In this study, the number of indicators is 14 items with a calculation of $14 \times 7$ = 98 samples (Ferdinand, 2006).

\section{Variable Identification}

Based on the problems and hypotheses proposed in the previous chapter, the variables to be studied are grouped into three variables, namely:

1. Dependent Variable in this study as $(Y)$ is a customer loyalty with the following indicators:

a. Repeat purchase

b. Shop reference

c. Not influenced by competitors

2. Independent Variable, in this study the variables categorized as independent are:

\section{X1: Product Diversity}

With the following indicators:
a. Product Brand Variations
b. Variation of Product Types
c. Variation in Size
d. Product Quality Variations

X2: Service Quality

With the following indicators:
a. Tangible
b. Reliability
c. Responsiveness
d. Assurance/ guarantee
e. Empathy

3. The Intervening variable $(Z)$ used is customer satisfaction with the following indicators:
a. Overall customer satisfaction
b. Suitability of Expectations

\section{Hypothesis}

Based on literature review and previous research as described above, the hypotheses developed in this study are:

H1: Product diversity has a direct effect on customer loyalty at Toko Pertanian Subur located in, Pace Nganjuk District.

H2: Quality of service has a direct effect on customer loyalty at Toko Pertanian Subur located in, Pace Nganjuk District. 
H3: Customer satisfaction has a direct effect on customer loyalty at Toko Pertanian Subur located in, Pace Nganjuk District.

H4: Customer satisfaction mediates the indirect effect between product diversity on customer loyalty at Toko Pertanian Subur located in, Pace Nganjuk District.

H5: Customer satisfaction mediates the indirect effect between service quality on customer loyalty at Toko Pertanian Subur located in, Pace Nganjuk District

\section{RESULTS AND DISCUSSION}

From the research conducted, the results can be seen as follows:

Table 2. Direct and Indirect Effect

\begin{tabular}{llllll}
\hline \multicolumn{1}{c}{ Variable } & \multicolumn{1}{c}{$\begin{array}{c}\text { Path } \\
\text { Coefficient }\end{array}$} & Direct & $\begin{array}{c}\text { Effect } \\
\text { Indirect }\end{array}$ & Total & Sig. \\
\hline X1 towards Z & 0.283 & 0.283 & - & 0.283 & Significant \\
X2 towards Z & 0.592 & 0.592 & - & 0.592 & Significant \\
X1 towards Y & 0.267 & 0.267 & - & 0.267 & Significant \\
X2 towards Y & 0.261 & 0.261 & - & 0.261 & Significant \\
Z towards Y & 0.251 & 0.251 & - & 0.251 & Significant \\
X1 towards Y & - & 0.283 & 0.251 & 0.071 & Significant \\
through Z & & & & & \\
X2 towards Y & - & 0.592 & 0.251 & 0.149 & Significant \\
through Z & & & & & \\
$\varepsilon 1$ & 0.367 & 0.367 & - & 0.367 & - \\
$\varepsilon 2$ & 0.627 & 0.627 & - & 0.627 & - \\
\hline
\end{tabular}

Source: Processed data, 2019

\section{The Effect of Product Diversity on Customer Loyalty Partially}

In determining the table, it is seen at the significance level of 0.05 where $\mathrm{df}=$ number of samples - number of variables $=98-2=96$. The table value of df 96 is 0.1986 . The value of tcount variable product diversity (X1) and customer loyalty $(Y) 2.655$. So, it can be concluded that tcount $>$ table (2.655> $0.1986)$ means that the variable product diversity (X1) has a significant impact on customer loyalty $(\mathrm{Y})$ partially. Meanwhile, the significance of product diversity $(\mathrm{X} 1)$ is 0.009 which is less than $5 \%(0.009<0.05)$, then it can be drawn that the product diversity variable has a significant effect towards customer loyalty $(\mathrm{Y})$ and the line coefficient is 0.267 ( $\rho \mathrm{YX} 1)$.

\section{Service Quality to Customer Loyalty Partially}

The table is seen at the significance level of 0.05 where $\mathrm{df}=$ number of samples - number of variables $=98-2=96$. The table value of df 96 is 0.1986 . The value of tcount the quality of service variable (X2) and customer 
loyalty $(\mathrm{Y}) 2.186$. It can be summarized that tcount $>$ table $(2.186>0.1986)$ means that the service quality variable (X2) has a significant effect on customer loyalty $(Y)$ partially. In the meantime, the significance of service quality (X2) is 0.031 , which is smaller than $5 \%(0.031<0.005)$, so it can be concluded that the product diversity variable has a significant effect on customer loyalty $(Y)$ and the line coefficient is 0.261 ( $\rho Y X 2)$.

\section{Customer Satisfaction towards Customer Loyalty Partially}

The table is seen at the significance level of 0.05 where $\mathrm{df}=$ number of samples - number of variables $=98-2=96$. The table value of df 96 is 0.1986 . The value of tcount variable customer satisfaction $(Z)$ and customer loyalty $(Y)$ is 2.029 . It means tcount $>$ table $(2.029>0.1986)$ signifies that the customer satisfaction variable (Z) has a significant effect on customer loyalty (Y) partially. Meanwhile, the result of customer satisfaction (Z) of 0.045 is smaller than $5 \%(0.045<0.05)$, so that the customer satisfaction variable $(Z)$ has a significant effect on customer loyalty $(Y)$ and the line coefficient is 0.251 $(\rho Y Z)$.

\section{The Effect of Product Diversity on Loyalty with Customer Satisfaction as an Intervening Variable}

The results of the direct effect of product diversity on customer satisfaction amounted to 0.283 . Whilst, the direct effect of customer satisfaction on customer loyalty is 0.251 . To calculate the indirect effect of product diversity on customer loyalty through customer satisfaction is by multiplying the beta value of product diversity on customer satisfaction with the beta value of customer satisfaction on customer loyalty, that is $0.283 \mathrm{x}$ $0.251=0.071$. By comparing the two results, it can be seen that the value of the direct effect $>$ the indirect effect. Thus, based on the calculations that have been done, the value of the indirect effect is 0.071 . This means that there is an indirect effect of product diversity on customer loyalty through customer satisfaction or $\mathrm{H} 4$ is rejected, customer satisfaction mediates the indirect effect between product diversity on customer loyalty at Toko Pertanian Subur in Pace Nganjuk District.

Effect of Service Quality on Loyalty with Customer Satisfaction as an Intervening Variable

The results of testing the direct effect of service quality on customer satisfaction amounted to 0.592. The number of direct effect of customer satisfaction on customer loyalty is 0.251 . Meanwhile, to calculate the indirect effect of service quality on loyalty towards customer satisfaction is by multiplying the beta value of service quality on customer satisfaction with the beta value of customer satisfaction on customer loyalty, namely $0.592 \mathrm{x}$ $0.251=0.149$. So, based on the calculations that have been done, the indirect effect value is 0.149 . It means that there is an indirect effect of service quality on customer loyalty through customer satisfaction $(\mathrm{H} 4)$ is 
rejected. This is because the value of the effect of service quality (X2) directly on customer loyalty is 0.261 . By comparing the two results it can be seen that the value of the direct effect> the indirect value.

\section{CONCLUSION}

Derived from the results of data analysis and discussion that has been described in previous chapters, it can be signified that there is influence on product diversity towards customer loyalty. The hypothesis testing results prove that product diversity has a direct effect on customer loyalty. This is verified by the tvalue of 2.655 with a significance level lower than $0.05(0.009$ $<0.05$ ) and a positive path coefficient of 0.267 . Second, there is effect of service quality on customer loyalty. The results of hypothesis testing prove that service quality has a direct effect on customer loyalty. This is evidenced by the tvalue of 2.186 with a significance level lower than $0.05(0.031<0.05)$ and a positive path coefficient of 0.261 . Third, the hypothesis testing results show that customer satisfaction has a direct effect on customer loyalty. This is confirmed by the tvalue of 2.029 with a significance level lower than $0.05(0.045$ $<0.05$ ) and a positive path coefficient of 0.251 . Fourth, it is found that between product diversity variables on loyalty through customer satisfaction, there is no mediating effect. It happens as the result of the influence of product diversity on customer loyalty value through satisfaction is smaller than the effect value of product diversity on customer loyalty directly, that is $0.071<0.267$. Finally, there is no mediating effect between service quality variables on loyalty through customer satisfaction. This is by reason of the value of the effect of service quality on customer loyalty through satisfaction is smaller than the effect value of product service quality on customer loyalty directly, as much as $0.149<0.261$

\section{REFERENCES}

Gunawan, L. \& Kempa, S. (2016). Pengaruh Kualitas Pelayanan Terhadap Loyalitas Konsumen dengan Kepuasan Konsumen sebagai Variabel Intervening di Toko BintangTerang. Agora, 4(1), 424-434

Hartono, R. (2018). Analisis Pengaruh Kualitas Pelayanan Terhadap Loyalitas Pelanggan dengan Kepuasan Pelanggan sebagai Variabel Intervening di Toko Kalimas. Agora.

Hasan, A. (2008). Marketing. Yogyakarta: Media Utama

Hasanah, U., \& Harti. (2012). Pengaruh Keragaman Menu, Harga dan Kualitas Pelayanan Terhadap Loyalitas Pelanggan dengan kepuasan Sebagai Variabel Intervening pada Waroeng "SS" (Spesial Sambel) Surabaya. Jurnal Pendidikan Tata Niaga, 3(2) : 1-11

Kotler, P., \& Keller, K.L. (2009). Manajemen Pemasaran (ed. 13). Jakarta: Erlangga Kotler, P. (2002). Manajemen Pemasaran Ed. Milenium. Jakarta: PT. Prehallindo Kotler, P. (2006). Manajemen Pemasaran (ed.12) Jilid 2. PT Prenhallindo: Jakarta Lupiyoadi, R. (2001). Manajemen Pemasaran Jasa. Salemba Empat: Jakarta 
Rivai, V. (2012). Islamic Marketing :Membangun Dan Mengembangkan Bisnis Dengan Praktik Marketing Rasulullah. Jakarta: PT Gramedia Pustaka Utama.

Simammora, H. (2004). Manajemen Pemasaran Internasional Jilid 1. Jakarta: Salemba Empat.

Tjiptono, F. (2005). Pemasaran Jasa (Ed. 1). Yogyakarta: Penerbit Banyumedia Publising

Tjiptono, F., \& Chandra, G. (2012). Pemasaran Strategik. Yogyakarta: Andi

Tjiptono, F. (2007). Strategi Pemasaran (Ed. 1).Yogyakarta: Andi Offset

Tjiptono, F. (1997). Strategi Pemasaran (Ed. 2). Yogyakarta: Andi Offset

Utami, C.W. (2010). Manajemen Ritel: Strategi dan Implementasi Oprasional Bisnis Ritel Modern di Indonesia (Ed.2). Jakarta: Salemba Empat 